\title{
STUDENTS' UNDERSTANDING LEVEL OF ONLINE TEACHING IN THE TECHNICAL AND VOCATIONAL EDUCATION AND TRAINING (TVET) SECTOR
}

\author{
Vijayaragunathan Srivishagan*, \\ Wanasundara Arachchilage Ishara Madhusankha, \\ Jayogha Chalanga Munasinghe, Chathuri Piumika Danthanarayana \\ and Haththotuwa Gamage Dayal Shamin Samarasinghe
}

University College of Matara, Sri Lanka

\begin{abstract}
Although online education is not a recently emerged concept, the popularity of the concept has been boosted with the pandemic COVID-19, where the students have to depend totally on online education and they have been framed in it forcefully irrespective of the fact whether online education suits all type of education, especially for the sectors where the practicality is given the priority such as in the Technical and Vocational Education and Training (TVET) sector. Therefore, there arises a need to investigate the understanding level of the students. The objectives of this research are to identify the students' understanding level of online teaching and to evaluate the relationship between the understanding level of students and online teaching methods. The population of the study was all the students in the TVET sector in Sri Lanka and the sample was 294 students from 6 university colleges. Structured questionnaires were distributed among the sample for data collection. Descriptive analysis and correlation analysis were employed in the data analysis. The results discovered that a majority of students understand the online theoretical lecture delivery but they lack infrastructure facilities to engage in the academic activities. There is a low level of understanding of practical lessons. Moreover, the results visualize a moderate positive relationship between the students' understanding level and online teaching methods. The researchers suggested that online teaching can be used for theory lectures in critical situations such as disasters but for the practical sessions, the student should physically be present to the field. Efficient strategies relevant to each type of professional qualification provided by the institutes should be implemented.
\end{abstract}

Keywords: Online Teaching, Student understanding level, TVET

Online teaching and learning have been viewed as the latest resource for the students' learning platforms during the pandemic situation. Therefore, the concept of free and global education has been abruptly changed to online and distance learning with the sudden closure of educational institutions. Along with this transformation, many online learning platforms such as digital learning management systems, collaboration platforms for live-video communication, massive open online courses (MOOCs), and tools for creating learning content have been established (De Giusti, 2020). However, the survival of the existing systems is presented with many defects on the part of learners as well as teachers. Therefore, as a solution to strengthen the system higher education institutions utilized existing Moodle-based learning management systems under university web servers. A similar system of online learning and teaching has been adopted to vocational training and education sector in Sri Lanka. 
However, irrespective of the efficiency of the online platforms, the vocational education sector has been drastically affected because of the online teaching platforms due to the difficulty of convincing the curriculum of the vocational studies. Apart from the lecture delivering, vocational studies mostly involve practical aspects of the existing knowledge and therefore teachers always face the challenge of imparting the practical component to the students in online platforms and the students' comprehensibility is severely affected. Therefore, the development of knowledge and practical experience of the students can be badly affected and made a negative impact on the effectiveness of understanding level of students on online teaching in the Technical and Vocational Education and Training (TVET) sector. Since online teaching has been introduced as a new concept during the COVID-19 pandemic, the lack of research conducted in Sri Lankan aspect is considered a major drawback. Therefore, there is an empirical gap to study the understanding of students' understanding of online teaching in the TVET sector.

To address this problem, two main objectives are expected to be achieved. Those are to identify the level of students' understanding of online teaching and to identify the relationship between different factors and understanding levels of students in online teaching in the TVET sector.

\section{Literature Review}

It's an accepted fact that online learning has recently become an important part of education in all levels of education from primary to higher education including the sector of vocational training (Gros \& García-Peñalvo, 2016). Nevertheless, many of the studies pointed out that online learning is not a new method of learning but a new method of knowledge imparting (Eickhoff, 2008). In fact, online teaching has been introduced in order to improve the efficiency of the vocational sector (Belaya, (2018). Many advantages of e-learning on the part of the student as well as the teacher have also been identified. According to Nguyen (2015), online learning saves traveling time to the educational facilities, and the learner is given the full autonomy to determine the time and the place of learning. This the temporal and spatial flexibility offered to teachers and learners which will in turn increase the motivation to learn, improve learning performance and reduce training costs. Howe and Knutzen (2013) and Zinkevich (2003) claim that online platforms of learning are created to make quick access for a large number of learners in long distance. Mandl and Kopp (2006) point out that online learning enables making "a transformation of the learning culture" by developing the creativity of the students which offer an innovative learning scenario.

But as Balanskat et al. (2006) pointed out, the integration of online teaching into the vocational sector is a very complex process with many different obstacles. Nevertheless, the teaching and learning process of the vocational sector is being recognized as different from that of the general system of tertiary or higher education. The students at the vocational sector need to perform diverse skills in order to become skilled workers (Lauglo \& Lillis, 1988). During the pandemic situation, e-learning has been recognized as the most productive way of imparting the knowledge to the students. However, this task has always been recognized as a challenge especially in the context of teaching. Maphosa and Mashau (2014) defined the role of a teacher in the vocational sector as someone who assists in gaining not only the knowledge but also the skills to compete in the working environment. Thus, teaching to develop necessary skills has been further emphasized. However, there 
arise the difficulties of teaching necessary skills in online learning platforms. Hasselbring and Glaser (2000) pointed out if the teachers are unable to use technology in teaching and learning, the lack of techniques will in turn affect the productivity of the lessons learned. Schoepp (2005) showed that not only teachers lack skills but also the use of diverse learning and teaching strategies will have a negative impact on the understanding of the learning content.

Researchers have identified certain obstacles in creating on-line learning platforms in the vocational sector and these obstacles include teacher behavior and attitude towards e-learning, and also the necessity of utilizing the modern technological infrastructure (Brolpito et al., 2016). According to Heuel and Feldmann (2014), the competency level of teachers and trainers will affect students' online learning level and thereby affect their general understanding of the lessons. However, apart from the competency level, several factors have affected the general understanding of the students in online learning platforms. Many studies have explored the impact of students and teachers' attitude in online learning sessions which in turn affect the understanding level of the students. Sunal et al. (2006) pointed out that the students' attitude can offer a greater impact on the understanding of the learning content and this is further strengthened with the acceptance of technology in the classroom. Understanding the behavior of the students has been further examined in this context. Davis (1992, as cited in Vallerand, 1997, and Venkatesh, 1999) presented different perspectives to predict the understanding levels of the students. It has also been examined that intrinsic and extrinsic motivation can be driving forces that determine behavioral intention to use students' understanding level.

According to Rockwell et al. (1999), the most important factor of online education is that students have a lot of opportunities to access TVET sector education through infrastructure facilities (internet facilities, technological devices). Another motivating factor is that online lectures enable a better communication platform for students with their instructor. Study materials are positively influenced for online education and instructors can increase students' outcomes positively. Attractive study materials and teaching methods motivate the students to attend online lectures always. However, instructors are expecting consistent infrastructure and technology such as the internet, teaching methods, study materials and pieces of equipment for online education. Online education is more effective when the institute provides more freedom to students and instructors and institutes should provide clear instructions and policies for online teaching. A conceptual framework (see Figure 1) has been developed that incorporates the student, instructor, and institutional factors that have been associated with students' understanding level of online study.

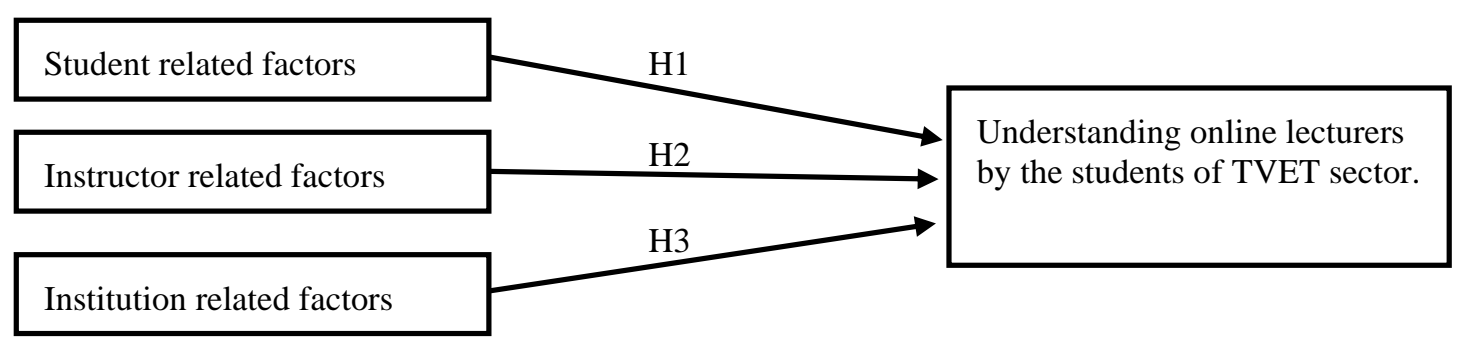

Figure 1. Conceptual Framework 


\section{Methodology}

The population of the study was all the students who are studying for their National Vocational Qualification (NVQ) from government TVET sector education institutes in Sri Lanka. According to the Tertiary and Vocational Education Commission (TVEC), there are 1126 government institutions that provide NVQ qualifications to the students in 2020. Most of these institutions provide NVQ level 03, 04, 05 and 06 qualifications. The sample was 294 students from six university colleges in Sri Lanka. The sample has been chosen according to the convenient sampling method due to the willingness of the sample to respond to the questioner. According to Dornyei (2007), convenience sampling is a type of nonprobability sampling method that the target population meet under certain practical criteria, such as access or the availability at a given time and willingness to participate by the responders.

Structured questionnaires were distributed among the sample for data collection online. The questionnaire included three main sections; the first section was to identify the demographic information of the students. The second section and the third section of the questionnaire were addressed to understand online lectures by the students of the TVET sector and independent variables (student-related factors; instructor related factors and institution related factors). The first section of the questionnaire included multiple-choice questions and section two and three included five-point Likert scale questions.

Descriptive analysis and Karl Pearson's coefficient of correlation were used for the data analysis. Literature suggested three main factors that can be affected on the understanding of the online teaching by the students. The descriptive analysis enables a determination of the students' level of understanding in online lectures. Karl Pearson's coefficient of correlation analysis leads researchers to identify the relationship between the selected factors and understanding online lecturers by the students of the TVET sector.

\section{Results and Discussion}

\section{Demographic factors of the respondents}

A majority of the sample represents "male students" and the age group of 20-25. Most students' monthly family income recorded between $40,000 \mathrm{LKR}$ to $50,000 \mathrm{LKR}$. The students represent management, civil engineering, engineering technology, applied and natural science departments.

\section{Descriptive analysis}

A descriptive analysis was employed in order to achieve the first objective, which is to identify the students' understanding level of online teaching. Mean and standard deviation are the analyzing parameters used under descriptive analysis. The statistical output of descriptive statistics was analyzed by using the following criteria.

$1.0<=\mathrm{X}<2.5$ Disagreed 
$2.5<=\mathrm{X}<3.5$ neither agreed nor disagreed

$3.5<=X<5.0$ Agreed

Table 1

Descriptive analysis

\begin{tabular}{llll}
\hline Dimensions & N & Mean & Std. Deviation \\
\hline Students' Understanding Level & 294 & 3.94 & .497 \\
The applications used to conduct online lectures are user friendly & 294 & 4.67 & .470 \\
I'm satisfied regarding the quality of the online lectures & 294 & 4.26 & .658 \\
Online lectures improve my theoretical knowledge & 294 & 4.52 & .500 \\
Online lectures improve practical knowledge & 294 & 2.31 & .673
\end{tabular}

Source: SPSS outcomes of field survey 2020.

According to Table 1, the mean value of all dimensions is greater than 3.5 except "Improve students' practical knowledge." Since the mean value is 3.94, which is higher than 3.5, the students, in aggregate, agreed that they can understand well the lectures conducted online. Moreover, the standard deviation of overall "students' online lecture understanding level" is 0.497 and it indicates that the mean value of "students' online lecture understanding level" is deviated by 0.497 . The mean value of "user-friendliness of the online applications" falls at 4.67 and it deviated by 0.470 . It indicates that the students almost satisfy applications used to conduct online lectures. The students are also satisfied with the "quality of the online lectures" since the mean value is 4.26 and it deviated by 0.658 . The online lectures improving the students' theoretical knowledge and mean value falls at 4.52. Moreover, the standard deviation is 0.5 which indicates the mean value of "improving theoretical knowledge" deviated by 0.5 . The mean value of "improving practical knowledge of students through online lectures" falls at 2.31 which means that the students, in aggregate, tended to disagree with the statement. Therefore, it can be concluded that the online lecture conducted for TVET sector students are only understandable for the students in the context theoretical lectures are being conducted. The online lectures are efficient only for theoretical lectures but the practical lessons need to be done in the physical classrooms.

\section{Correlation Analysis}

Karl Pearson coefficient of correlations analysis is used in identifying the relationship between different factors and understanding levels of students on online teaching in TVET sector. The results of the correlation analysis are shown in Table 2.

Table 2

Correlation analysis

\begin{tabular}{llll}
\hline Variables & $\mathrm{N}$ & Pearson Correlation & Sig. (2-tailed) \\
\hline Students related factors & 294 & .449 & $<.001$ \\
Instructor related factors & 294 & .457 & $<.001$ \\
Institution related factors & 294 & .324 & $<.001$ \\
\hline
\end{tabular}

Source: SPSS outcomes of field survey 2020. 
According to Table 2, the correlation coefficient value of all independent variables falls at positive values that means that each of the independent variables has a positive relationship with the dependent variable of the study. A correlation value of "Student related factors" is 0.449 and it means the student-related factors and "students' understanding level of online lectures" had a moderate positive relationship. Correlation values of "instructor related factors" and "institution related factors" are 0.457 and 0.324 respectively. It indicates that "instructor related factors" and "institution related factors" also have a moderate positive relationship with "students' understanding level of online lectures." Moreover, the significant value of all factors is less than 0.001 and it confirms that all the correlation coefficient values are significant. Therefore, all three hypotheses of the study are accepted and the null hypothesis is rejected.

\section{Conclusion}

The research has been conducted in order to identify students' understanding level of online teaching in technical and vocational education and training (TVET) sector. Descriptive analyses have been used in this paper and results revealed that online lectures are user friendly, when evaluating students' theoretical knowledge. Those are reached the level of understanding mean level 3.94, however, "Online lectures improve practical knowledge" is very low mean level than the standard level. Moreover, it is clearly stated that online lectures only develop the theoretical knowledge but it is not suitable for the practical lessons. On the other hand, the Tertiary and Vocational Education Commission (TVEC) sector mainly based on the practical and vocational studies. As the data analysis clearly concludes, online lectures are theoretically effective for TVEC sector students and also not suitable or ineffective for practical session for TVEC sector students.

In this research, it has been revealed that there were three factors that mainly affected the online teaching such as student-related factors, instructor-related factors and institution-related factors. Moreover, all three factors (independent variables) were positively related to students' understanding of online study (dependent variable). Furthermore, these three factors positively affect the online study progress of the students. The scope of the study is limited to some institutions of the TVEC sector, due to closure of many institutions during the COVID-19 pandemic. Moreover, most of the TVEC sectors have already initiated conducting online or virtual learning platforms due to COVID-19 situation. Furthermore, most of the institutions maintained blinded online learning apps and also avoided virtual e-learning due to the unavailability of networks and facilities. Therefore, this study suggests the future strategy as follows: identify the student, instructor and each factor's perspective and how to implement the practical knowledge via virtual studies.

\section{Acknowledgement}

Foremost, we would like to thank our respondents from the TVEC sector students and instructors who responded our question, regarding the online studies and effectiveness and for sparing their valuable time in contributing their ideas to the development of this research. 


\section{References}

Balanskat, A., Blamire, R., \& Kefala, S. (2006). The ICT impact report. European Schoolnet, 1, 1-71.

Belaya, V. (2018). The use of e-learning in vocational education and training (VET): Systematization of existing theoretical approaches. Journal of Education and Learning, 7(5), 92-101.

Brolpito, A., Lightfoot, M., Radišic, J., \& Šcepanovic, D. (2016). Digital and online learning in vocational education and training in Serbia: A case study. European Training Foundation.

De Giusti, A. (2020). Policy brief: Education during COVID-19 and beyond. Revista Iberoamericana de Tecnología en Educación y Educación en Tecnología, 26, e12.

Dornyei, Z., 2007. Research methods in applied linguistics. Oxford University Press.

Eickhoff, L. A. (2008). e-Learning in der Sportausbildung und-weiterbildung, Probleme Perspektiven und Tendenzen [Unpublished doctoral dissertation]. Deutsche Sporthochschule Köln.

Gros, B., \& García-Peñalvo, F. J. (2016). Future trends in the design strategies and technological affordances of e-learning. Springer.

Hasselbring, T. S., \& Glaser, C. H. W. (2000). Use of computer technology to help students with special needs. The future of children, 102-122.

Heuel, E., \& Feldmann, B. (2014). Quality standards for e-learning in vocational education and training: The certified European e-tutor. In The $2^{\text {nd }}$ international workshop on learning technology for education in cloud (pp. 93-100). Springer.

Howe, F., \& Knutzen, S. (2013). Digitale Medien in der gewerblich-technischen Berufsausbildung. Einsatzmöglichkeiten digitaler Medien in Lern-und Arbeitsaufgaben. http://datenreport. bibb. de/media2013/expertise_howe-knutzen. pdf

Lauglo, J., \& Lillis, K. (1988). Vocationalizing education: An international perspective. Pergamon Press.

Mandl, H., \& Kopp, B. (2006). Blended learning: Forschungsfragen und perspektiven.

Maphosa, C., \& Mashau, S. T. (2014). Examining the ideal 21st century teacher-education curriculum. International Journal of Educational Sciences, 7(2), 319-327.

Nguyen, T. (2015). The effectiveness of online learning: Beyond no significant difference and future horizons. MERLOT Journal of Online Learning and Teaching, 11(2), 309-319.

Rockwell, S. K., Schauer, J., Fritz, S., \& Marx, D. B. (1999). Incentives and obstacles influencing higher education faculty and administrators to teach via distance. Faculty Publications: Agricultural Leadership, Education \& Communication Department, 53.

Schoepp, K. (2005). Barriers to technology integration in a technology-rich environment. Learning and Teaching in Higher Education: Gulf Perspectives, 2(1), 1-24.

Sunal, D. W., Wright, E. L., \& Bland, J. (Eds.). (2006). Reform in undergraduate science teaching for the $21^{\text {st }}$ century. IAP.

Vallerand, R. J. (1997). Toward a hierarchical model of intrinsic and extrinsic motivation. In Advances in experimental social psychology (Vol. 29, pp. 271-360). Academic Press.

Venkatesh, V. (1999). Creation of favorable user perceptions: Exploring the role of intrinsic motivation. MIS quarterly, 239-260.

Zinkevich, M. (2003). Online convex programming and generalized infinitesimal gradient ascent. In Proceedings of the $20^{\text {th }}$ international conference on machine learning (ICML-03) (pp. 928936). 